University at Buffalo School of Law

Digital Commons @ University at Buffalo School of Law

\title{
American Legal Theory and American Legal Education: A Snake Swallowing Its Tail?
}

John Henry Schlegel

University at Buffalo School of Law

Follow this and additional works at: https://digitalcommons.law.buffalo.edu/journal_articles

Part of the Legal Education Commons, and the Legal Theory Commons

\section{Recommended Citation}

John H. Schlegel, American Legal Theory and American Legal Education: A Snake Swallowing Its Tail?, 12 German L.J. 67 (2011).

Available at: https://digitalcommons.law.buffalo.edu/journal_articles/449

\section{C. ${ }_{\text {COPYRIGHT }}^{\text {N }}$}

This Article is brought to you for free and open access by the Faculty Scholarship at Digital Commons @ University at Buffalo School of Law. It has been accepted for inclusion in Journal Articles by an authorized administrator of Digital Commons @ University at Buffalo School of Law. For more information, please contact lawscholar@buffalo.edu. 


\title{
Articles
}

\section{American Legal Theory and American Legal Education: A Snake Swallowing its Tail?}

\author{
By John Henry Schlegel
}

My story is a story about American Legal Realism. It is part of an attempt to understand what Realism was by addressing the question, "Why is the study of Realism a subject of legal history and not of current events?" Of course, the "answer" to such a question is made up of several partial answers, of which what follows is but one. Others would talk about the relationship between legal doctrine and capitalist economic development or about legal theory and political philosophy or about legal theory and legal practice, to name a few examples. However, this partial answer can best be approached by examining how a simple idea about law - the liberal idea of the rule of law in its guise as the "rule theory of law"1 - has had in its rise and in its demise an impact on legal education and to attempt to understand why that is so. My attempt however, requires that I start my story back aways with Christopher Columbus Langdell and the Harvard Law School.

\section{A. The Classical Order $1870-1920$}

Langdell is one of the more obvious enigmas of legal intellectual history. Tony Chase ${ }^{2}$ and Tom Grey ${ }^{3}$ to the contrary notwithstanding, Grant Gilmore ${ }^{4}$ was right. Langdell was gentle, essentially stupid man who clung onto a simple idea with all the tenacity that only the

\footnotetext{
*Professor of Law, State University of New York at Buffalo. B.A., Northwestern University, 1964; J.D., University of Chicago, 1967. Author: From the Yale Experience, 28 Buffalo Law Review 459 (1979); American Legal Realism and Empirical Social Science, The Singular Case of Underhill Moore, 29 Buffalo Law Review 195 (1980); Notes Toward and Intimate, Affectionate and Opinionated History of the Conference on Critical Legal Studies, 36 Stanford Law Review 391 (1984); Langdell's Legacy: or the Case of the Empty Envelope, 36 Stanford Law Review 1517 (1984). American Legal Realism and Empirical Social Science (1995); Of Duncan, Peter and Thomas Kuhn, 22 Cardozo Law Review 1061 (2001); But Pierre, If We Can't Think Normatively, What are We to Do? 57 Miami Law Review 955 (2003); CLS Wasn't Killed By a Question, 58 Alabama Law Review 967(2007); Law and Economic Change the Short Twentieth Century in 3 Cambridge History of Law In America 563 (2008); On the Many Flavors of Capitalism, or Reflections on Schumpeter's Ghost, 56 Buffalo Law Review 965 (2009).

${ }^{1}$ Norbert Reich supplied this elegant substitute for all sorts of awkward phrases.

${ }^{2}$ Anthony Chase, The Birth of the Modern Law School, 23 AM. J. LEGAL HIST. 329 (1979); Anthony Chase, Origins of Modern Professional Education: The Harvard Case Method Conceived as Clinical Instruction in Law, 5 Nova L. J. 323 (1981)

${ }^{3}$ Thomas C. Grey, Langdell's Orthodoxy, 45 U. PITT. L. REV. 1 (1983)

${ }^{4}$ Grant Gilmore, The Ages of American LaW 42 (1977)
} 
stupid can muster. Nor can Langdell's revolution be saved by attaching it to Harvard's president, Charles Eliot. ${ }^{5}$ Eliot may have known something about scientific education, including medical education, but he could have known nothing about legal education if he believed that studying cases was a clinical education or that a law library was a laboratory. And yet, Langdell and Eliot intuitively understood something that few others did in the years after the Civil War. They understood one way, at least, of fitting legal education to what would be, with their help of course, the dominant legal theory of the time.

Robert Gordon ${ }^{6}$, Tom Grey ${ }^{7}$ and Duncan Kennedy ${ }^{8}$ each have attempted to isolate this dominant late-nineteenth century legal theory that Gordon calls liberal legal science. I have nothing against these versions; I nevertheless find a later version of the theory, that of Joseph Beale in the mid-twentieth century, like Bach's belated exemplification of the baroque, clearer for my purposes. In his great treatise on the conflict of laws, Beale argued that law was made up of three things: principles, "the largest portion even of the particular law of a state", standards and rules, some of which are "quite arbitrary in their operation". ${ }^{9}$ These three things, however, are not generally arbitrary; rather, they "tend to form a single homogeneous philosophical system". ${ }^{10}$ "Changes made by legislation and by wrong decisions", by the arbitrary pieces of the law which are respectively "small" and "uncommon", "constitute the greater part of the peculiar local law of any jurisdiction, as distinguished from the doctrine of the prevailing legal system". ${ }^{11}$ It is this prevailing legal system, "the common law", "general bodies of principle [which] exist and are capable of scientific development", that is the subject of study in "any law school of more than local importance". ${ }^{12}$ Due to the great proliferation of decisions, "[m]ore and more the development of the law by decisions has been complimented by a development of the law through the study and experience of scholars". ${ }^{13}$ This general system, which "exists apart from positive law", and thus "neither by legislation nor by judicial legislation can be

\footnotetext{
${ }^{5}$ Which Tony Chase has clearly tried to do in his work.

${ }^{6}$ Robert W. Gordon, Legal Thought and Legal Practice in the Age of American Enterprise 1870-1920, in PROFESSIONS AND PRofessional IDEOLOGIES In AMERICA, 70 (Gerald L. Geison ed., 1983)

${ }^{7}$ See, supra, note 3

8 Duncan Kennedy, Toward an Historical Understanding of Legal Consciousness: The Case of Classical Legal Thought in America, 1850-1940, in RESEARCH IN LAW AND SOCIOLOGY 3 (Stephen Spitzer ed., 1980)

9 Joseph H. Beale, A Treatise on the Conflict of LaWs 2 (1935)

${ }^{10} / d ., 23$.

${ }^{11}$ Id. 25.

${ }^{12}$ Id. , 27-28.

${ }^{13} / d ., 28$.
} 
changed", is in force because it is accepted as in force. ${ }^{14}$ Yet, it is certain that the common law changes; "[T]his must be true, or the science of law, differing from all other sciences, would be unprogressive". ${ }^{15}$ Change in the law comes from "change of the professional opinion about it", a professional opinion that is molded by the judges and by the law teachers and other "legal thinkers who are not judges" ${ }^{16}$ But no matter what changes are made in law, a legal system must have certain characteristics. It must be general, "since justice requires equality of treatment for all persons, and this means generality"; universal, since "it is unthinkable in a civilized country that any act should fall outside of the domain of law"; continuous, since "society needs to know the law in advance of judicial action upon it"; just, since "it is impossible at every moment to depend upon brute force for the administration and enforcement of law"; and predictable, since "the principle function of law is the prevention of disputes" by giving advice to "clients as to the quality of contemplated acts". ${ }^{17}$

As a description of the American legal system in operation in 1935 when this was written, Beale's construction is fantabulous and yet it is a remarkable piece of work for the way that it fits into the ideology of the larger society and into Langdell's law school. Let me back into the matter of the relationship between the rule theory of law as a form of liberal legal science and the ideology of the larger society by looking more carefully at Langdell.

Although Tony Chase seems to have decided that Eliot was the dominant force, ${ }^{18}$ it is Langdell who interests me more. Reading Langdell's annual reports in an eye-opener. The man was a numerologist, a sort of primitive version of Holmes' man of statistics, if not economics. Langdell's peculiar, very sensitive seismograph charted and attempted to explain the most minute variations in enrollment, tuition receipts, library acquisitions and the like. ${ }^{19}$ Indeed, while it is asserted that he spoke so little because of his faith in his system, ${ }^{20}$ the truth is that he spoke much, though very little about legal education and that

\footnotetext{
${ }^{14}$ Id., 30.

${ }^{15}$ Id., 39.

${ }^{16}$ Id., 40 .

${ }^{17}$ Id. , 45-48.

${ }^{18}$ Origins of Modern Professional Education (note 2). But cf. Anthony Chase, Lawyer Training in the Age of the Department Store, 78 Nw. U. L. REv. 893, 906-08 (1983).

${ }^{19}$ See, e.g., Langdell, Annual Report on the Law School, in ANNUAL REPORT OF THE PRESIDENT AND TREASURER OF HARVARD College 1883-84, 100-107; Langdell, Annual Report on the Law School, in ANNUAL REPORTS OF THE PRESIDENT AND Treasurer of HARVARD College 1884-85, 112-16; Langdell, Annual Report on the Law School, In ANNUAL RePORTS OF the PRESident AND TREASURer of HARVARD College 1887-88, 92-105.
}

${ }^{20}$ Eugene Wambaugh, Professor Langdell - A View of His Career, 20 HARV. L. REV. 1 (1906) 
much of what he said about legal education was absolutely inconsequential. ${ }^{21}$ Indeed, I seriously doubt that Langdell really understood anything about the revolution that was brought about in his name, except that he had fathered a new subspecies of lawyer - the full-time academic. ${ }^{22}$ That is, unless, one assumes that the old man really believed that law was a system of rules to be applied to concrete cases.

I confess that I have always had a hard time deciding what I think that Langdell, and here I use him as an eponym for an entire generation of elite lawyers, believed. Surely, this generation talked as if law was a system of rules - they spent enough time looking for the historical origins of these rules and trying to come to a "true" understanding of them. And yet it was simultaneously clear that the rules were really not the important elements in the Langdellian system, much less the cases, the supposed lynchpin of the case method. It was the principles that animated the system, that tested the rules and the cases. ${ }^{23}$ The law was thus better described as a system of principles than a system of rules.

I doubt that Langdell managed to fool himself and others about the lack of difference between a system of rules and a system of principles. For me the then common distinction between arguing a case on principle and arguing it on precedent demonstrates that others understood the difference. And yet, and yet what? And yet at times Langdell and others talked as if they did not know the difference. Perhaps such is what ideologies are made of, things one knows but does not know, and yet seeing law, and especially theories about law, as ideology has its problems. Who is listening? Ideologies imply the presence of auditors and if the ideology is for other lawyers and elite friends, somehow the effort seems wasted. Law as an elaborate mental teddy bear, as bed time stories for lazy lawyers, strikes me, quite simply, as implausible.

\footnotetext{
${ }^{21}$ Langdell wrote about 200 pages of annual reports. In addition he penned the famous CHRISTOPHER COLUMBUS langdell, Preface to a Selection of Cases on the LaW of Contracts VII (1871); Christopher Columbus Langdell, The Harvard Law School, 1869-1894, 2 HARV. GRAD. MAG. 490 (1894); Speech at 250th Anniversary Dinner, 3 L. Quar. Rev. 123 (1887); and Speech at the 25th Anniversary of Christopher Columbus Langdell as Dean of Harvard Law School, 29 AM. L. Rev. 605 (1895). Out of this only the Preface; the 250th Anniversary Dinner containing the famous passages on legal science, portions of the reports of 1873-74 (importance of division into classes, library as laboratory), 1976-77 (admission to bar in New York, division of bar into attorneys and counsellors) and 1886-87 (importance of a thorough professional education in the science of law, necessity for scholarships to encourage such study); and the Deanship anniversary dinner (listing accomplishments) can even vaguely be said to have anything to do with legal education. Of this, only the brief passages on legal science, which are hopelessly confused can be said to be other than decanal clap trap.

${ }^{22}$ The Harvard Law School 1869-1894 (note 21), 479-98

${ }^{23}$ Robert Gordon was the first person to point this out to me. A good illustration is found in the story about Langdell's equity course where he found Lumley v. Wagner to be simply wrong. See, Joseph H. Beale, Professor Langdell - His later Teaching Days, 20 HARV. L. REV. 9, 10 (1906), and in the oft quoted statement, "The vast majority [of cases] are useless, and worse than useless, for any purpose of systematic study". PREFACE TO A SELECTION OF CASES ON THE LAW OF CONTRACTS (note 21), viii.
} 
Still the question of audience is important. Concededly, the rule of law is an ideology, a shared understanding about political order, that, like all such understandings, makes some things acceptable and others not. But this ideology, in its guise of the rule of theory of law, cannot plausibly be described as being directed by the lawyers out into the community. Rather it is deep within the community down to the level of older sisters bossing younger brothers by telling them to "buckle up" because "its the law" or telling their fathers to "slow down", speeding is "against the law". But in this guise, the rule theory of law is for lawyers a rather simpleminded thing, implausible as a serious explanation of their work. Yet it cannot be wholly ignored. To the extent that an ideological justification of a lawyer's own activities is necessary, it is, if not essential, at least desirable, that the adopted justification, the explanation of the self to the self, fit tolerably well within the larger ideology of the community. It is this tension between the ideology of the larger community and the construction of a narrower justification of the lawyer's work that gives Langdell's ideas and all of late nineteenth century legal thought its peculiar half in, half out of focus quality, the sense of comfortably saying contradictory things one after another. For law can't both be the application of rules derived from cases and the application of principles that prove some of the cases to be wrong. Nevertheless, if the dominant ideology sees law as the application of pre-existing rules by judges in an even-handed way, the Langdellian theory is not a bad attempt to fit the reality of chaotic often contradictory decisions of not always beyond reproach judicial officers into the ideology. The notion of law as a body of principles somehow both abstracted from, and independent of, actual decisions, which principles are elaborated by an identifiable "method" and applied by the judges usually, but not invariably, correctly, may be a brooding omnipresence, but it both preserves law application and recognizes actual diversity. Moreover, at the more abstract level of political theory this notion "solves" questions about the justifiability of the decisions of an unelected judiciary - of their acceptability within a democratic political system, their freedom from the taint of personal or group interest - by combining authoritative premises for decision with a determinative technique of decision. Legal science as method, "the extraction of general principles by means of historical study [of cases] and the arrangement of them in rational relation to one another", ${ }^{24}$ provided both the premises and the technique. The process of abstraction of principles from the particulars of cases yielded the premises with, of course, the intervention of a purifying lens (a combination of a critical theory of history, the appeal of examples from comparable institutions and the natural reason of the well educated lawyer ${ }^{25}$ to free principle from the "warping by bad precedent", and then was mirrored in the process of application of principles so purified to cases. Together the two were the process of legal reasoning, the technique that yielded the rule of law.

\footnotetext{
${ }^{24}$ See, supra, note $6,87$.

${ }^{25}$ Id. $, 84,88$.
} 
This model parallels the substantive side of Langdell's law school. The pure private law curriculum that he designed was supposed to allow the student to derive the applicable legal principle from a multitude of narrowly relevant cases, often arranged in historical order and to apply the principles thus derived in the newly instituted course exams and the more ancient moot courts ${ }^{26}$. It was thus a curriculum cleansed both of inhibiting local legislation and of warping precedent. Of the rest of the Langdellian reforms, the most notable, the Socratic dialog, harkened back to the catechistical recitation sessions of the New England colleges. It was hardly important to Langdell, who abandoned it as his eyesight failed, ${ }^{27}$ but may have been a serious educational innovation in law for it moved the question of justification more to the center of the student-teacher relationship. ${ }^{28}$ The longer, three year curriculum and the required college degree are part of the other conscious innovation that Langdell made the development of the new sub-pieces in the profession, the full-time law teacher. ${ }^{29}$ The old man considered it one of his great innovations $^{30}$ and it surely was for it was the full-time academics on both sides of the Atlantic $^{31}$ who put together the treatises and in the United States, the casebooks, an innovation designed to limit the wear and tear on the library, ${ }^{32}$ that entombed the substantive program of legal science. However, the relationship of these scholars to Langdellian legal theory and thus to the rule theory of law takes a while to explain.

The reference to law teachers which sticks out somewhat uncomfortably in Beale's argument is, of course, a clue to the fact that Langdell could not have brought forth "his" revolution by himself. He needed and received the assistance from over one hundred young, and few not so young, teachers of law throughout the land each of whom brought the case method to his school in the ten years on either side of the turn of the century. ${ }^{33}$ Creating this corps of fulltime teachers of law to replace the part-time practitionerteachers who had populated American law schools in the years before 1910 was Langdell's most significant achievement and one he recognized long before it was clear that this

\footnotetext{
${ }^{26}$ Robert SteVens, LaW SCHOOL: Legal EducAtion in AMERICA from the 1850's to the 1980's (1983), 35-42, 51-57

${ }^{27}$ The CentenNial History of the HaRVARd LaW SCHOOL 1817-1917 (1918), 36

${ }^{28}$ Al Katz pointed this out to me years ago.

${ }^{29}$ See, supra, note $26,38,60-61$.

${ }^{30}$ See, supra, note 22.

${ }^{31}$ As David Sugarman has now made crystal clear. David Sugarman, Legal Theory, The Common Law Mind and The Making of the Text Book Tradition, in LEGAL THEORY AND COMMON LAW 26 (William Twining ed., 1986).

32 See, Christopher Columbus Langdell, Annual Report on the Law School, in ANNUAL REPORTS OF THE PRESIDENT AND TREASURER OF HARVARD COLlEge 1890-91, 104, 116.

33 See, John Henry Schlegel, Between the Harvard Founders and the American Legal Realists: The Professionalization of the American Law Professor, 35 J. LEGAL ED. 311 (1985).
} 
change would carry the day. ${ }^{34}$ However, the growth of Midwestern and western states brought with it the establishment of public universities throughout the land, each of which, in emulation of Michigan, expressed the need to have a state law school. These schools and a few of the larger, private universities, were the ones who most quickly adopted the case system of legal education, largely as they aped elite status and hired graduates of Harvard, Columbia and Chicago who had studied under that system.

Elsewhere, of course, legal education, particularly private legal education unaffiliated or quite loosely affiliated with a university, was growing like crazy as well. ${ }^{35}$ Indeed, proportionately, this segment of legal education was growing more rapidly than the state schools and the more elite private schools that had also followed Langdell's lead. The great increase in urban population, due in part to immigration from Europe, was accompanied by a great increase in the demand for legal education, particularly part-time, night school legal education. Teaching in most of these schools was pure, indeed occasionally stridently pure, pre-Langdell text and lecture and the schools personned largely by part-time practitioner-teachers. ${ }^{36}$ The course of study at these schools was often the same length as, and thus effectively shorter than, the course for full-time day students at the more elite schools and the cost, once the opportunity costs of foregone income are considered, thus less than, or at most equal to, the cost of a legal education at even a public law school. The economic threat to the elite schools with full-time faculty, and to practitioners generally, from cheap ways of entering the profession was thus quite real.

Not surprisingly, the bar and the elite schools attempted to choke off the avenues of cheap access to the profession, though for different reasons. ${ }^{37}$ The bar, of course, was interested in price fixing; it wished to raise, or at least maintain, price by decreasing supply. The role of the law professors was more complex. They too wished to protect their market; a world full of cut rate versions of their law schools made it difficult to justify their relatively privileged position. So uniting with the bar to require that each and every law student have a college degree and spend three full-time years, or their equivalent, in law school, the obvious "standard" both groups strived for, was in the interest of the academics and yet

\footnotetext{
${ }^{34}$ The issue was still a live one as late as 1910. Langdell's strongest statements came fifteen years earlier. See, supra, note 22.

${ }^{35}$ See, supra, note 26 , in the source of most of this paragraph.

${ }^{36}$ See, e.g., Thomas Koenig \& Michael Rustad, The Challenge to Hierarchy in Legal Education: Suffolk and the Night Law School Movement, in RESEARCH IN LAW, DEVIANCE AND SOCIAL CONTROL ,189 (1985).

${ }^{37}$ What follows is a summary of the argument in Schlegel, supra, note 33. That in turn draws heavily on MAGALI Larson, The Rise of Professionalism (1977) and Jerold Auerbach, Unequal Justice: LAWYers and Social Change iN MODERN AMERICAN (1976). I have also wrestled with this problem in John Henry Schlegel, Langdell's Legacy, or the Case of the Empty Envelope, 36 STANFORD LAW REVIEW (Stan. L. Rev.) 1517 (1984). I confess that I suspect that my friends in C.L.S. may well find this argument to be too functionalist and for this reason have chosen to ignore it. On this question see, infra, note 39.
} 
this is only part of the story. Price fixing only works for standardized products, like No. 2 bituminous coal or Saudi Arabian Light Crude Oil. But, given that legal jobs and legal skills are anything but uniform, many different kinds or types of legal education might have been appropriate for law students, depending on the type of practice each wanted to enter. Thus, unless one wishes to settle for a part of the entire market, as Langdell may have initially wished to do, ${ }^{38}$ in order to gain control of a market in law knowledge one "needs" ${ }^{139}$ to establish a single legal education assertedly appropriate to the entire market. The uniformity of degree requirements went part way toward solving this problem, yet as anyone who has observed an undergraduate school will soon notice, a program of uniform graduation requirements, such as would have satisfied the practicing lawyers' needs, standing alone can turn out quite varying graduates - historians and literatures, sociologists and biologists. The time, and thus money, spent in satisfying requirements can be spent in quite different ways, since it is devoted to an intangible knowledge. So, to effectively control the market, one has to control what is taught; the intellectual content that is put into the program of study. Here the content of the Langdellian theory of law had a direct use.

\footnotetext{
${ }^{38}$ Christopher Columbus Langdell, Annual Report on Law School, in ANNUAL REPORTS OF PRESIDENT AND TREASURER OF HARVARD COLLEGE 1876-77, 82, 88-92.

${ }^{39}$ To speak of "needs" raises the ugly question of "functionalism". I use "needs" with a certain malice. I am tired of hearing functionalism dismissed as if it were somehow stupid to assert that the products of human activity such as law have or serve functions. While I can understand how one might be upset at the politics of the functionalists of the Post-World War II period, that upset is not an objection to functionalist explanations. A hammer and a crescent wrench may both be used to drive nails into wood. But a bit of work at the task is likely to demonstrate that one of these tools was designed to, is functional for the indicated task and I dare say that an anthropologist in 10,000 years will have little difficulty coming to the same conclusion.
}

Now, of course, some products of human activity, like legal education or negligence, are substantially more complicated to dope out than hammers and crescent wrenches. Indeed, it may be said that such complex products have multiple functions. (Then again, so do tools. A crescent wrench may be used to drive nails and, as I just checked out, a claw hammer, thought not a ball peen hammer, to tighten bolts and nuts.) But that only implies that the task of understanding the function is more difficult for complex entities.

There is the problem of necessary relationship, I suppose. To say, as I am saying above, that the structure of legal education had a function is not to say that only this structure could have served that function. State legislation directly limiting entry into the profession or a reinvigorated bar coupled with stringent, essentially class biased apprenticeship requirements could have done as well. And understanding why one route rather than others was taken in a society often tells much about that society. (Here the legislative route was unavailable because the relatively less elite legislatures would not go along; they even were unwilling to go along with the lesser entry requirements sought by the law schools. The apprenticeship route was unavailable because the corporate bar simply had no time to train the myriad of apprentices it needed; its desire to support university based education was a recognition that it did not wish the task.) But the existence of hypothetical alternatives or even of similar societies where different alternatives were actually taken does not undermine an assertion about the function of a product of human activity, at least unless one is caught in the clutches of a rather virulent sociological or historical positivism. 
There are many possible contents to the notion of what it is to be lawyer, all the way from simple scrivener to the public statesman of Ciceronian virtue. ${ }^{40}$ Many of these notions have been trotted out from time to time. The Langdellian version, the lawyer as the expositor of legal principles collected and rationalized through the use of legal science, had many advantages. First, as a matter of pure social status it was far from unimportant to this nascent professional group, traditionally looked down upon as "failed" practitioners or "retired" judges, that its intellectual product mirrored the work of the judge. The claim to equal partnership in the work of the legal profession as a whole was often heard at this time and generally based on the unity of the work of the judge and the jurist. ${ }^{41}$ Second, it was surely important that the Langdellian vision was dominant, or more aptly gaining dominance, at the time. One did not have to blaze a path but rather only swell a parade. Third, the Langdellian vision was useful in the university.

Useful how? During these years the American University, as we know it, was taking shape. ${ }^{42}$ Specialized academic disciplines unknown to the New England college, such as psychology, economics or history, chemistry, physics, or biology, English, modern languages, or fine arts, were creating themselves. ${ }^{43}$ The process, known by the unilluminating, but nevertheless accurate, title "professionalization", was producing a balkanization of knowledge as each piece of the academy attempted to do what the lawyer's were attempting: carve out a piece of the academic turf that would allow that group exclusive control over the production of knowledge in that area. ${ }^{44}$ Again, constrict supply to increase price. The law professors needed to create a market, not from scratch as did the sociologists, but in the sense of excluding other potential producers of the same good from doing so. So in terms of exclusive control, the academic lawyers faced the same problem as all other nascent disciplines.

Here, in terms of establishing exclusive control, is where the various notions of what it is to be a lawyer made some difference. The notion of the lawyer as scrivener really cut the academics out; teaching a handicraft was inappropriate to the university as Langdell himself noticed. At the same time too broad a role risked other intellectual poachers.

\footnotetext{
${ }^{40}$ See, supra, note $6,82-87$ gives content to the notion of the lawyers as the public statesman of Ciceronian virtue.

${ }^{41}$ See, supra, note $33,321$.

${ }^{42}$ See, generally, LAURENCE VeYSEY, EMERGENCE OF THE AMERICAN UNIVERSITY (1965).

${ }^{43}$ See, supra, note 33, 313-14 for a rough description of the process and for sources on some of these disciplines.

${ }^{44}$ Id., 319-25. A similar, though by no means identical argument to what follows for the balance of this paper is Arthur Jacobson, Modern American Jurisprudence and the Problem of Power, 6 CARDozo L. Rev. 693 (1985). For its sheer elegance and the power of its categories, Jacobson's paper repays careful reading. At the same time, I am not convinced that the process we both seek to describe is as exclusively intellectual as his paper implies nor do I think he would be convinced that the process is an heavily social as I think it is.
} 
Ciceronian virtue suggested that rhetoric was a relevant skill, maybe moral philosophy; maker of public policy suggested that economics and political science might be central. However, Langdell's world of the private law litigator, his rules neatly ordered and logically defensible, suggested no other claimants. It was at once too technical for any other academic discipline to claim and simultaneously too general, indeed airy and theoretical, for any practicing lawyer to suggest as matter appropriate to an apprenticeship. As the content for a discipline it was a good match to the academics' need. And the rhetoric of legal science made it better still. Legal science was a method, or at least appeared to be one, and an identifiable method was the hallmark of any discipline in the academy. ${ }^{45}$ Equally importantly it was a method so tedious and time consuming that the practicing bar could be expected to leave it to the academics and simply reap its fruits. Capitalizing on this division of intellectual labor seemed easy, especially since the rest of the university bore the same relationship to the law school as the society at large did to the legal profession. If legal science in its guise as the rule theory of law fit tolerably well with the rule of law ideology in the society at large then, though adopted for a different purpose, it nevertheless ought to fit well in the academy also. And so it did.

Much of the intellectual product of these years before World War I, for example, the great treatises, Wigmore on Evidence and Williston on Contracts, were the primary monuments to this ideal of legal science and thus a part of the creation of the identity of the law professors. But the production of the first generation of casebooks, most notable of which is, of course, Gray's six volumes on property, ${ }^{46}$ but also including such lesser lights as Bohlen's torts book ${ }^{47}$ and Huffcut's Agency book, ${ }^{48}$ was part of the same project. The casebook presented the law, the rules, scientifically. And not all of these attempts were successful either; Wigmore's torts book clearly got it wrong and was left by the wayside. ${ }^{49}$ Other activities contributed in a less direct way. Great gobs of print were spilled on standardization of courses, degrees and libraries. ${ }^{50}$ Efforts were made to increase the intellectual range of the professoriate through publication of materials on European legal

\footnotetext{
${ }^{45}$ See, supra, note 33; Schlegel (note 37) provides support for this proposition. As a brief supplement, I would suggest that the failure of political science and sociology to identify a method appropriate to the discipline accounts for much of the sense that neither is a discipline, as well as for the attraction of a general statistical, empirical method for both disciplines.

46 John Gray, Select CASes And Other Authorities of the LaW of Property (1988-92)

${ }^{47}$ Francis Bohlen, CASES ON THE LAW OF TORTS (1915)

${ }^{48}$ ERnest HuffCut, CASes on the Law of Agency (1895)

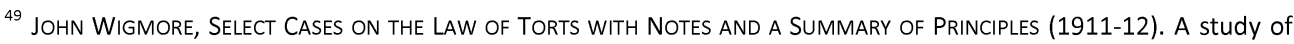
why this book was rejected might well illuminate the contours of the late nineteenth and early twentieth century legal academic's intellectual world.

${ }^{50}$ See, supra, note $33,321$.
} 
history and philosophy. ${ }^{51}$ Major theoretical attempts were offered by Thayer and later Ames to describe the nature of the work of the law professor. Thayer emphasized research, and gave scant attention to "the difficult main work of teaching". ${ }^{52}$ Ames, six years later, put a greater emphasis on teaching young men how to "think like a lawyer". ${ }^{53}$ Simultaneously much work was put directly into raising standards by increasing the number of years of pre-legal, and of legal, education, raising the minimum size of faculty, decreasing the maximum number of courses taught, and, of course, increasing the size of libraries. ${ }^{54}$ And much effort went into keeping the teaching of law the teaching of pure law, as is testified to by both the famous Beale/Ames correspondence with William Rainey Harper over the wish of Ernest Freund to inject such novelties as international law, administrative law, criminology, finance, railroad transportation, accounting and banking into the curriculum at the new University of Chicago Law School ${ }^{55}$ and the long fight at Columbia over that school's relationship with the School of Political Science. ${ }^{56}$

The more narrowly jurisprudential writings of the time were much of the same stripe. Here the best bridge into that literature is Wesley N. Hohfeld's, A Vital School of Jurisprudence and Law, the grandest plan for a law school ever concocted. ${ }^{57}$ Recognizing six varieties of jurisprudence - historical, comparative, analytic, teleological, legislative and empirical; several neglected aspects to the law students' education, including the required courses in legal history and jurisprudence and required reading in the history of the legal profession; and the need for a department devoted to the "civic and cultural study of legal institutions by non-professional college students", ${ }^{58}$ Hohfeld proposed nothing less than a temple to the law professoriate. Roscoe Pound's theory of interests is of much the same stripe. ${ }^{59}$

\footnotetext{
${ }^{51}$ No adequate discussion of the impact, if any, of either the Continental Legal History Series or the Modern Legal Philosophy series is available, perhaps, because there was none. The latter is treated briefly in John Henry Schlegel, American Legal Realism and Empirical Social Science: The Singular Case of Underhill Moore, 29 BUfFALO LAW REVIEW (Buff. L. Rev.) 195, 202 n. 20.

52 James Thayer, The Teaching of English Law at Universities, 9 HARV. L. REV. 169, 183 (1895)

53 James Ames, The Vocation of the Law Professor, in J. AMES, LeCtURES ON LEGAL HISTORY 354 (1913); James Ames, Remarks, in Proceedings of the SeVenth Annual Meeting of the Association of American law Schools 16 (1907). The precise origin of the phrase "thinking like a lawyer" is unknown to me.

${ }^{54}$ See, supra, note $21,92-103$.

${ }^{55}$ Id. $39-40$.

${ }^{56}$ Foundation for Research, in LEGAL HISTORY, A HISTORY OF THE SCHOOL OF LAW COLUMBIA UNIVERSITY 85-89 (1955).

${ }^{57}$ Wesley Hohfeld, A Vital School of Law and Jurisprudence: Have Universities Awakened to the Enlarged Opportunities and Responsibilities of the Present Day, in Proceedings of the Fourteenth AnNual Meeting of the ASSOCIATION OF AMERICAN LAW SCHOOLS 76 (1914).

${ }^{58}$ Id., 128.

59 Pound's work, scattered throughout the pages of the law reviews, is collected in his multi-volume treatise, Jurisprudence (1959) which is largely a compendium of his original articles, complete with original footnotes, with
} 
Pound argued that the point of law is to secure interests of people or groups or governments. Interests, that is "the claims or demands or desires for which or about which the law has to make some provision if civilization is to be maintained or furthered and society is not to be disrupted or dissolved", need to be first inventoried, generalized, and classified, then one has to "select and determine the interests which the law should recognize", fix their limits, "weight the means by which the law may secure interests", and "work out principles of valuation of interests". ${ }^{60}$ That is a mighty tall order. Indeed an heroic task fit for a whole generation of law professors.

Pound's actual execution of the task is, however, instructive. Other than for some work on the means of securing interests, a subject curiously shifted to a negative - the limits of effective legal action - Pound stopped at classification, which is not to underestimate the compendiousness of that classification. Individual interests were divided into those of personality - the physical person, freedom of will, honor and reputation, privacy and sensibility, and belief and opinion; of domestic relations; and of substance - control of corporeal things, freedom of industry and contract, claims to promised advantage, claims to be secured against outsiders in economically advantageous relations with others, freedom of association and continuity of employment. Public interests, in comparison, were comparatively more limited, confined as they were to the interests of the state as a juristic person - again matters of personality and substance, and as a guardian of social interests. Social interests were, however, more elaborate - general security, security of social institutions, general morals, conservation of social resources, general progress and the individual life. ${ }^{61}$ In contrast to this rather sloppy teleological jurisprudence, consider Hohfeld's more elegant, but no less grand, scheme of analytical jurisprudence. Hohfeld's Fundamental Legal Conceptions was nothing less than attempt to explain "all possible kinds of jural (i.e., legal or equitable) interests" as an "aid in the understanding and in the solution of practical, everyday problems of the law". ${ }^{62}$ His efforts led to the production of two tables:

only limited new material. His version of the theory of interests is contained in vol. 3 from pages 5-341. NATHAN ROSCOE POUND, JURISPRUDENCE (1959) 3, 5-341 (1959).

${ }^{60}$ Id., 16, 22.

${ }^{61}$ Id., $101-341$.

${ }^{62}$ Wesley Hohfeld, Some Fundamental Legal Conceptions as Applied in Judicial Reasoning, 23 YALE L.J. 16, 20 (1913) 


\begin{tabular}{|l|l|l|l|l|}
\hline Jural Opposites & $\begin{array}{l}\text { right } \\
\text { no-right }\end{array}$ & $\begin{array}{l}\text { privilege } \\
\text { duty }\end{array}$ & $\begin{array}{l}\text { power } \\
\text { disability }\end{array}$ & $\begin{array}{l}\text { immunity } \\
\text { liability }\end{array}$ \\
\hline Jural Correlatives & $\begin{array}{l}\text { right } \\
\text { duty }\end{array}$ & $\begin{array}{l}\text { privilege } \\
\text { no-right }\end{array}$ & $\begin{array}{l}\text { power } \\
\text { liability }\end{array}$ & $\begin{array}{l}\text { immunity } \\
\text { disability }\end{array}$ \\
\hline
\end{tabular}

and a surprising amount of technical commentary.

The precise details of either system are less important than the overall activity. Both Pound and Hohfeld were busy doing legal science as Langdell, Thayer, and Ames had adjured them to do and in ways these elders would have understood. The object set out was to establish a discipline and then set to work in that discipline. But not just any discipline. The discipline of law, pure law. Thus, Hohfeld's work was in fact limited to "judicial reasoning", primarily in cases trusts and other equitable relations. And the grandest part of his vital school, the one devoted to jurisprudence, was in fact a school for training law professors; mere lawyers went to the school of law where torts, contracts and property were taught. Similarly, Pound's scheme is essentially one centered in common law. When he had to actually look at a legislatively created interest, for example, in "continuity of employment" under the Wagner Act, he was essentially unable to do so. ${ }^{64}$ And likewise when he came to the point of having to value interests he could offer a notable caution, still lost on all today: one must be careful to compare interests "on the same plane. If we put one as an individual interest and the other as a social interest we may decide the question in advance in one very way of putting it". ${ }^{65}$ But, on the precisely relevant, indeed crucial, point of how to value interests once on the same plane he had to admit that the search for a method "is futile" and so lapsed into a jurisprudential schmorgasbord of alternative methods. ${ }^{66}$ For both men, the system was grand, but it hid a rather narrow heart of common law adjudication.

Of course today, Pound's willingness to recognize that legal method simpliciter was not determinative in valuing interests is what seems important, what makes him seem in some ways modern, just as his efforts at recognizing social interests and his early assertion that there were in fact causes in the law to the popular dissatisfaction with the administration of justice, ${ }^{67}$ that make him in political terms progressive. Similarly, Hohfeld's system surely helped lay bare the way that legal science in practice manipulated its basic terms to come

\footnotetext{
${ }^{63}$ Id., 30.

${ }^{64}$ See, supra, note 59, 233-35.

${ }^{65}$ Id., 328.

${ }^{66}$ Id., 330.

67 Nathan Roscoe Pound, The Causes of Popular Dissatisfaction with the Administration of Justice, in 29 Proceedings of the American Bar AsSociation, 400 (1906).
} 
out with desired results. ${ }^{68}$ Yet, one would be mistaken if one were to over emphasize these matters. Both men are thoroughly locked in the world of Langdell's legal science and of the professionalization of the law professoriate.

How deeply locked in that world both men were can be seen from Hohfeld's reaction to the work of a colleague and contemporary at Stanford, Joseph W. Bingham. In 1913, Bingham published a piece in the Michigan Law Review entitled "What is the Law?" In a major sense it is a piece straight out of analytic legal science, for Bingham's stated purpose as to "focus attention on each of several sorts of elements which exist in the field of legal study and their essential differences and correlations". ${ }^{69}$ And yet, as he set out on this work something strange emerged. "All the ambitious attempts to define this field agree that it consists of a system of rules and principles enforced by political authority. I believe that this idea is fundamentally erroneous and that it is a bar to a scientific understanding of our law". ${ }^{70}$ And what was this "scientific understanding" Bingham spoke about? It was not the "organized, generalized knowledge" of Langdell and his followers, but rather "the acquisition of an ability to predict that described efforts will or will not follow from definite concrete conditions and forces". ${ }^{71}$ And so viewed, law is "the concrete operations and effects", the "external sequences of phenomena" of "authoritative government" which by "observation, report, inductive and deductive reasoning and the other implements of scientific investigation, may be generalized into rules and principles". ${ }^{72}$ And so Bingham proposed "a science of law" in place of legal science. In reviewing the piece, the editor of The Green Bag, a vaguely scholarly legal magazine, commented "Law is thus conceived of as something objective, as a certain aspect of human society in action, and the jurist's attitude toward his special field would not be unlike that of the biologist or naturalist". ${ }^{73}$ He then observed "This interpretation does violence to the plain and natural meaning of words. By law we clearly mean ... not a real or imaginary state of fact, but a rule or principle ... Legal science is not concerned with the delineation of external reality, but with an ideal material which offers a valuation rather than a description of human activity". ${ }^{74}$ Of this thoroughly traditional reply to an essentially revolutionary idea, Hohfeld wrote to this

\footnotetext{
${ }^{68}$ See, Joseph Singer, The Legal Rights Debate in Analytical Jurisprudence from Bentham to Hohfeld, WISC. L. REV. $975,1050-59$ (1982).

${ }^{69}$ Joseph Bingham, What is the Law?, $11 \mathrm{MICH}$. L. REV. 12 (1912)

${ }^{70}$ Id. 3.

${ }^{71}$ Id., 4 .

${ }^{72}$ Id. 9.

${ }^{73}$ Jurisprudence Not an Objective Science, 25 The Green Bag 74 (1913)

${ }^{74}$ Id. 75.
} 
friend Pound that the author in The Green Bag took Bingham's article "somewhat too seriously; but that in its general tendency, his criticism was correct". ${ }^{75}$

\section{B. American Legal Realism 1920-1940}

Such a firm and direct reassertion of the traditional perspective is, of course, the hallmark of a confident orthodoxy. Yet, in less than fifteen years that orthodoxy would be shattered. All hell would break loose - its name American Legal Realism. What then was Realism? Viewed from the traditional perspective of intellectual history as collage, it was the casual, if not adventitious, gathering of ideas from Holmes - the prediction theory of law ${ }^{76}$, Gray the radical assertion that judges always made law ${ }^{77}$; Pound - the attack on mechanical jurisprudence and the program of sociological jurisprudence, the jurisprudence of interests ${ }^{78}$, Hohfeld - the destruction of the logic of rights ${ }^{79}$, and Bingham - the twentieth century notion of science as empiric not analytic activity ${ }^{80}$, and the forging of these ideas into a theory of judicial decision-making that emphasized the subjective element in the judicial process. This notion is not wrong, it just misses the point, as Hohfeld missed the point of Bingham's article. Realism's meaning is to be found in its social context.

With the coming of the famous Root report of 1922, legitimating the night law schools on condition that their program be as long as that of the full-time day schools, and accepting the American Bar Association as the accrediting agency for all law schools, the position of the legal academic in the legal profession became firmly established. ${ }^{81}$ If the battle for recognition had not been won unconditionally, at least it had not been lost. The American Bar Association would work to raise standards in a way that would benefit the academics. So much for institutional structures. On the intellectual side of law teaching, the great legal science project was completed. ${ }^{82}$ The law had been given its initial correct formulation;

\footnotetext{
75 Wesley N. Hohfeld to Roscoe Pound, Feb. 25, 1913, in Roscoe POUnd PAPERS, Harvard Law School Archives, Cambridge, Massachusetts

${ }^{76}$ Oliver Holmes, The Path of Law, 10 HARV. L. Rev. 457 (1897)

77 John GRAY, THE NATURE AND SOURCES OF LAW (1909), a proposition uttered for a thoroughly conservative purpose.

${ }^{78}$ Nathan Roscoe Pound, Mechanical Jurisprudence, 8 Colum. L. ReV. 605 (1908); Nathan Roscoe Pound, The Scope and Purpose of Sociological Jurisprudence, 24 HARV. L. REV. 598 (1911), 25 HARV. L. REV. 515 (1912)

${ }^{79}$ See, text and supra, note 68.

${ }^{80}$ See, supra, text at notes 69-72.

${ }^{81}$ See, supra, note $26,112-123$.

${ }^{82}$ See, John Henry Schlegel, Searching for Archimedes - Legal Education, Legal Scholarship, and Liberal Ideology, 34 J. LEGAL ED. 103, 107 (1984).
} 
what was left was to restate it. Beyond that devastatingly tedious, but clearly compelling project, all that was necessary was to monitor the slow changes in the corpus of law - a new wrinkle in consideration here, an extension of damage theory there. The prospect was, I suspect, a rewarding one to the people who had built the edifice, comforting to the normal scientists among the young, and thoroughly disconcerting to the more intellectually impatient of any age. Schools were prospering; faculties were slowly increasing in size, if only in response to demographic trends; and a certain post-war prosperity and optimism was fueling the dreamers in the academy. "Why dream?" one might ask. For years it had been drummed into the head of every young law professor that the proper home of a law school was in a university. ${ }^{83}$ By 1920 there were actually universities in virtually every Midwestern state, and some really large universities in the east. Demography had done for the university as a whole what it had done for the law schools. And so specialized knowledge abounded. That specialized knowledge was there for the taking, if only one knew what to do with it.

For a young man of even a mildly left persuasion the "what to do with it" was obvious. This was a deeply conservative period in American history. The post-war red scare that led to the Palmer raids and the Sacco-Vanzetti case were all symptoms of an America that was fat, happy and wanted to be left alone. A reactionary Supreme Court, a war, and a modicum of formal success had sapped progressivism of much of its force. And yet, there were still radical alternatives available. Glowing reports still emanated from the great Soviet experiment; The Masses and similar journals were a notable literary force; and a real Socialist Party ran real candidates that got substantial votes. For liberals in a reactionary time, REFORM was the answer. Apply the knowledge of the university to the solution of social problems.

The idea had been tried in La Follette's Wisconsin, with much noise, if not much success outside of agricultural technology. But, for law an impediment to reform was legal theory and, of course, the Supreme Court. Langdellian legal science, didn't really admit of reform. Oh, it was supposed to provide for change derived from the change in legal opinion based on changed social circumstances, but as Bob Gordon has argued there was a good deal of substantive bite to it as well. Legal science aimed "to make all (adult male) persons juristically equal, to recast all legal obligations so that they derived from an exercise of will, and to standardize the definition of rights and duties". ${ }^{84}$ This meant that all private law liability was to be derived not from status, but from contract seen as promise and from fault, both seen as objective, not private, manifestations of conduct. ${ }^{85}$ It also meant that all statutory enactments were "to provide a more efficient procedural mechanism for

\footnotetext{
${ }^{83}$ See, Schlegel, supra, note 51, 233-34.

${ }^{84}$ See, supra, note $6,89$.

${ }^{85} / d$.
} 
vindicating common law rights" or otherwise be seen as arbitrary, when not unconstitutional, elements of local law that kept the law from being a perfect system and were thus undesirable. ${ }^{86}$

If one wanted to attack this system one could of course attack the doctrinal pieces - formal equality, objective theory of contract and so on, as had been done by dissenting scholars since $1890 .^{87}$ And such attacks were mounted, but to them were added a new, theoretical attack on legal science as Beale had described it. Starting with Bingham's attack on legal science for not being scientific, scholars attacked both aspects of the Langdellian solution to the problem of political legitimacy. The premises of law were sought to be shown to be not authoritative and the technique, not determinative. The materials used for this effort were commonplace enough - Dewey on science and scientific method ${ }^{88}$, some Hohfeld, some Pound, a dollop of Freud ${ }^{89}$, a nod to Holmes and Corbin ${ }^{90}$ and Cardozo ${ }^{91}$, all ripped out of context and used for purposes their authors would have disagreed with, but mostly it was home brew.

Law was not rules; it was politics. As such it needed to be seen and taught in a way that presented the social issues directly. Thus, the old categories of contract, tort and the like ought to be dropped and in their place substituted "functional", i.e., showing the functions performed by the legal institution (all Realists were, at heart, functionalist anthropologists and institutional economists), categories, like risk bearing and business form and labor law or trade regulation ${ }^{92}$. Substantive reforms, largely legislative in nature, were to be pursued after applying truly scientific method to the study of social life and legal institutions. The problem of the automobile accident was to be solved much like workman's

\footnotetext{
${ }^{86}$ Id., 98.

${ }^{87}$ WILLIAM TWINING, KaRL LleWellyn AND THE Realist MOVEMENT (1973); William Twining, Talk About Realism, 60 NEW YORK UNIVERSITY LAW REVIEW (N.Y.U. L. Rev.) 329 (1985) attempts to develop the notion of a "dissenting tradition" in American jurisprudence, though in a thoroughly implicit fashion. Twining has used the phrase in conversation for years. He puts in the class of pre-Realist dissenters, Holmes, Gray, Corbin, Hohfeld, Pound and Cardozo. In addition to the works of these scholars noted above one needs to recognize BENJAMIN CARDOZO, THE NATURE OF THE JUDICIAL PROCESS (1922); Arthur Corbin, The Law and the Judges, 3 Yale Review 234 (1914); Nathan Roscoe Pound, Liberty of Contract, 18 YALE L. J. 462 (1909).

${ }^{88}$ John Dewey, Logical Method and Law, 10 CORNELL L. Q. 17 (1924) is the usual cite. In fact Dewey's ideas on science were scattered all over until consolidated in JOHN DEWEY, LOGIC (1938)

${ }^{89}$ Here, I speak of Jerome Frank's attachment to Freud's theory of the unconscious that permeates JEROME FRANK, LAW AND THE MODERN MIND (1930)

${ }^{90}$ Corbin, supra, note 87

${ }^{91}$ CARDOZO, supra, note 87

${ }^{92}$ See, Schlegel, supra, note 51, 208-09.
} 
compensation, ${ }^{93}$ that of improvident credit by tighter bankruptcy law. ${ }^{94}$ In general, law was to be transformed from its role in specifying "combat zones of free conduct in which individuals might do as they willed without fear of legal reprisal" ${ }^{195}$ to that of a positive agency of social control. ${ }^{96}$

While all of this was going on at the intellectual level, in the law school's themselves there was just as much ferment. ${ }^{97}$ Among the less elite schools there was, of course, the great and continuing pressure of rising standards, tempered eventually by the monetary pressures associated with the Great Depression. More pre-legal education, more books, more teachers all were the talk of the times. At the more elite schools, other than Harvard, where for a while Pound dealt ruthlessly with innovation, ${ }^{98}$ the first visible crack in the teaching orthodoxy of large class, Socratic dialog came with the introduction of seminars into the curriculum, first for graduate and honors students, then for all students. Selective admissions, too, had its first highly tentative go-round, a real break from the tradition of admitting all who could pay and then flunking out a third. Columbia tried a wholesale curriculum revision designed to switch from assuming or ignoring knowledge of, to explicitly presenting, the "nonlegal social structure"; to shift focus from appellate opinions; and to focus on statutory law. And actual empirical research got carried by law professors working in law schools. ${ }^{99}$ Equally important, the first total, sustained criticism of academic legal education by an insider since Langdell's revolution was penned: Llewellyn's On What's Wrong with So-Called Legal Education. ${ }^{100}$ He found it "inept, factory-ridden, wasteful, defective, and empty" since "not rules, but doing, is what we seek to train men for" and the doing had changed radically from the "blurred composite photograph of the countryplus-city lawyer of about 1870" that was in the mind of "the great case-book pioneers". ${ }^{101}$

It would be a mistake even to suggest that the Realist's critique, for that is what it was, and educational reforms, limited as they were, escaped criticism or triumphed over night. In time, seminars spread everywhere, as did selective admissions, but at least in the first year

\footnotetext{
${ }^{93}$ See, John Henry Schlegel, American Legal Realism and Empirical Social Science: From the Yale Experience, 28 Buff. L. REV. 459 (1979), 532-38

${ }^{94}$ Id. , 522-32, 541-42.

${ }^{95}$ See, supra, note 6,88 .

${ }^{96}$ Id. , 94-96.

${ }^{97}$ Much of what follows in this paragraph summarizes R. Stevens, supra, note 26 , at 172-199.

${ }^{98}$ Id., 136-37.

${ }^{99}$ See, Schlegel (notes 51 and 93).

${ }^{100}$ Karl Llewellyn, On What is Wrong with So-Called Legal Education, 35 COL. L. REV. 65 (1935)

101 Id., 653.
} 
program and for much of the balance, at the end of the Realist challenge the curriculum largely still fit in Langdell's categories - tort, contract, property, crime, corporations and so on. Empirical legal research inside the law school died out for years and social fact seldom made it into the law school in any systematic way. And yet it would be wrong to see that Realism had little impact on legal education. For Realism killed Langdellian legal science.

Although, just as Realism burst on the scene, the American Law Institute's great Restatement project, the crown of legal science, got underway, ${ }^{102}$ the Restatements have tuned out to be more of a tombstone for legal science, than a capstone. From the beginning, Realism's critics understood the threat. Two examples should suffice. In 1928, at an A.A.L.S. symposium on "Modern Movements in Legal Education", Joseph Beale, speaking "for the old men", noted that, "I look back on my work, and I am not dissatisfied with it". ${ }^{103}$ He then opined, "Now, there is teaching of law, and there is teaching of other sciences. We thought that, in order to teach a class of students to become useful members of the bar, we should not teach them things; we should teach them to be something. In other words, the object of our endeavors was not to make them think what law is about, but to make them think like lawyers". ${ }^{104}$ Realism proposed to teach students to think what law was about, to adopt the outside, external, objective perspective, treating law as "a certain aspect of human society in action". ${ }^{105}$ As such, as Beale understood, Realism doomed legal science. As a viable intellectual force it was finished if Realism was put into practice.

A more comprehensive criticism seven years later by Herman Kantorowicz, a refugee from Nazi terror, is equally poignant in its explicit defense of legal science. ${ }^{106}$ Kantorowicz argued of Realism that , "[t]he substantive theory is that the law is not a body of rules but of facts; the formal theory, that legal science is not a rational but an empirical science". ${ }^{107}$ And then observed not that "these theories are simply untrue", but they are "exaggerations of the truth". ${ }^{108}$ Most importantly, these are "doctrines which threaten the quiet progress of science". ${ }^{109}$ How can this be true? Curiously, Kantorowicz never says, but

\footnotetext{
${ }^{102}$ See, supra, note 82, 107; Schlegel, supra, note 51, 234.

103 Joseph Beale, Discussion, in Handbook And Proceedings of the TWenty-EIghth ANNuAl Meeting of the Association OF AMERICAN LAW SCHOOLS 53 (1928)

${ }^{104} / d$.

${ }^{105}$ See, supra, note $73,74$.

${ }^{106}$ Herman Kantorowicz, Some Rationalism about Realism, 43 Yale L. J. 1240 (1934).

${ }^{107}$ Id., 1240.

${ }^{108} / d$.

${ }^{109}$ Id., 1242.
} 
his argument, really a nice compendium of arguments against Realism generally, boils down to this. Law cannot be facts because then we would have to teach facts not rules in law school, study facts as the science of law, and be unable to distinguish fact from law for purposes of charging a jury or limiting appellate jurisdiction. Similarly legal science cannot be empirical because if it were, judges could never decide new cases for there would be no experience to guide him, new statutes could not be interpreted and clear rules such as "the rule of the Constitution that the President must be 35 years of age could not be law, and it would, therefore, not be unconstitutional to make Colonel Lindbergh President". ${ }^{110}$

The reductio ad absurdum, recognized by the author as such, conceals an important point. From an internal perspective, from that of the judge or jurist, though not necessarily the lawyer, the external, critical perspective made no sense. To look at the rule of law, at the rule theory of law, as a fact and not as a norm was to break its power. To do so sundered the unity between the work of the judge and the jurist, a unity that was part of the attraction to legal science for the academic lawyer, and, equally importantly, part of his claim to a special role as the expositor of legal science, as a German legal academic, even of the party of the left, could quite readily see. It was, in fact, not just the end of that claim, but the more importantly of the coherent professional identity carefully forged but a generation before. That would not do. That threatened the quiet progress of science.

What then of Realism? If it was so potent a critique as to demolish the whole idea of legal science, why is it passé ? Why write of it as history rather than as current events? Well there are the usual reasons, the conscription of many of its partisans into the administrative and judicial apparatus of the New Deal, the death of others and the continuing economic contraction of the Depression that cut budgets for research and teaching innovation. More important, however, is a factor Kantorowicz wryly alludes to when he speaks of the potential for cooperation between American and German jurists as a result of "present events in Germany, like the even more memorable accomplishments of the Turks in 1453" (the fall of Constantinople). ${ }^{111}$

The rise of Fascism in Europe was paradoxically the fall of Realism in America. Criticisms of Realism for its interest in the "is", in the outside, empiricist understanding of the law, rather than the "ought", the insider perspective of legal science, led to claims that Realism was a positivism in which whatever was the law was acceptable law. ${ }^{112}$ Put to one side the obvious objection that the entire point to the empiricist thrust of Realism was to

\footnotetext{
${ }^{110}$ Id., 1251.

${ }^{111}$ Id., 1253.

112 EdWARd Purcell, The Crisis in Democratic Theory: SCIentific Naturalism AND the Problem of Value (1973) lays out the entire literature which ranges from the serious and sensible, LON FULLER, LAW IN QUEST OF ITSELF (1940), to the silly and offensive Philip Mechem, The Jurisprudence of Despair, 21 IOWA L. REV. 669 (1936).
} 
understand how the law was in fact working in order to provide a secure basis for criticism and, ultimately, reform; put to one side the objection that legal science had, in fact, been more supportive of existing law and that it relied primarily on a relatively weak and limited tool for criticism and reform - logic. The anti-Realist criticism was made in law, as in other fields, and in the face of a thoroughly positivist and increasingly obviously evil regime in Germany and of the revelations about Stalinist repression in Russia that tainted all left politics in a way that even the Spanish Civil War could not redeem, the criticism stuck. Llewellyn and others began back tracking, began turning to safer projects like contracts and the commercial code; the Catholic law school right wing began to be heard; and then, all at once, everything was over as America dived into World War II.

\section{Post War Developments 1945-1965}

During the War, the law schools virtually shut down. ${ }^{113}$ Many schools enrolled no more than half a dozen students in a class. Many small private schools, largely ones with unaccredited part-time programs, closed, never to reopen. When the war was over, the surviving schools were flooded with students, most all of whom were entitled to G.I. Bill educational assistance. The accredited law schools, particularly the state schools, took this occasion to rise to their patriotic duty, even to the extent of expanding enrollments above pre-war levels and of offering year round, no summer vacation, two year programs so that "the boys" could "catch up". No sooner had this influx of students begun to wind down, when the onset of the Korean War guaranteed the continued existence of G.I. Bill students and funds. The result was that by increasing enrollment and using a government subsidy to reduce cost, the elite and not so elite accredited law schools both paid for the costs of higher standards - four years of college was now the universal norm, larger faculties and libraries an affordable fixture - and simultaneously kept most of the closed law schools from reopening and drove most of the remaining unaccredited schools out of business. In almost all cases state legislation ratified these events. By 1950 potential law students were faced with a clearly socially stratified ladder of options for law school with the bottom rung the few remaining part-time night programs, followed by the joint night and day programs, then the weaker, exclusively day, state and private programs that graded imperceptibly into the most elite of such programs, all private schools - Harvard, Yale and Columbia. And, whatever the choice available to him, the student was served up pretty much an identical curriculum, centered on the great, private common law subjects that had made up the curriculum before the World War I.

Had nothing changed? Well, the practice of law had changed and changed significantly with the late New Deal and immediate post-war growth of the statutory specialties - labor, securities, taxation, anti-trust, trade regulation, and general regulatory practices. The

${ }^{113}$ All of this paragraph and much of the next are derived from R. Stevens, see, supra, note 26, 205-231. 
upper-division curriculum reflected this change somewhat, as did the more occasional appearance of other basics like corporate finance, estate planning and zoning and of esoteric seminars like communication law. And, in the old common law courses, if one listened closely, one heard a new language spoken. Legal rules, still the staple of classroom discussion, were no longer justified on the grounds of their logical relationship with other rules or principles. Yes, that hierarchical system of justification was gone. Instead, what one heard in classrooms was talk about the policy behind the rules, each rule taken on its own. It was as if, in Duncan Kennedy's words, "the temple had been torn down and in its place was put a well manicured lawn. All rules were equal and all were one inch high". ${ }^{114}$

How this had happened, how a bastard form of sociological jurisprudence triumphed, is a still obscure story, but the central clue, I wish to suggest, can be found in the failure of a coherent program for reform put forth in an often cited (but surely largely unread for it is largely unreadable), article published by Harold Lasswell, a famous political scientist, and Myres McDougal, an early defender of Realism, but of a younger generation: Legal Education and Public Policy: Professional Training in the Public Interest. ${ }^{115}$ The point of the article was to lay out a plan for "refashioning ancient educational practices to serve insistent contemporary needs", work to be done immediately so as to be in place when the war was over. ${ }^{116}$ With an explicit desire to clarify "fundamental issues", the authors asserted directly, "the proper function of our law school is ... to contribute to the training of policy-makers for the ever more complete achievement of democratic values that constitute the professed ends of the American polity". ${ }^{117}$ And why was this so? "[D]emocratic values have been on the wane in recent years. The dominant trends of world politics have been away from the symbols and practices of a free society and toward the slogans, doctrines and structures of despotism". ${ }^{118}$ Lawyers could be blamed for this reversal of fortune because they are, "even when not ... a 'maker' of policy, the one indispensible adviser of every responsible policy-maker of our society". ${ }^{119}$ And the prescription for reform was nothing short of total. "[A]n adequate training must therefore include experiences that aid the developing lawyer to acquire certain skills of thought: goal thinking, trend-thinking and scientific thinking. The student needs to clarify his moral values ...; he needs to orient himself to past trends and future probabilities; finally, he

\footnotetext{
${ }^{114}$ Duncan disowns ever having said this. The attribution is nevertheless correct and stealing someone else's metaphor, even a disowned metaphor, is a high crime.

115 Harold Lasswell \& Myres McDougal, Legal Education and Public Policy: Professional Training in the Public Interest, 52 YALE L. J. 205 (1943)

${ }^{116}$ Id., 203.

${ }^{117}$ /d., 206.

${ }^{118}$ Id., 207.

${ }^{119}$ Id., 208.
} 
needs to acquire the scientific knowledge and skills necessary to implement objectives within the context of contemporary trends". ${ }^{120}$ And to implement this objective, Laswell and McDougal proposed a complete curriculum reform away from the doctrinal organization and toward organization by focus on influential policy-makers, values and skills.

The details of the scheme are essentially unimportant for present purposes. No law school has ever even proposed to adopt it. What is important to notice is that an explicitly radical piece coming out of the Realist ethos at Yale chose to yoke Poundian sociological jurisprudence to Realist empiricism and cover the entire package with democratic values. As a paper strategy the idea was nothing short of genius. Reverse the association of Realism with despotism by explicitly embracing, indeed trumpeting, democratic values. Unfortunately, neither author had done their trend thinking carefully. What sold instead can be seen in a little piece by Barton Leach of Harvard, critical of McDougal's efforts in a property casebook, called Property Law in Two Packages. ${ }^{121}$

Leach saw two objectives to legal education - to prepare lawyers "to assume direction of all phases of the areas of personal conflict inherent in a complex society and economy" and "to provide a very large proportion of national leadership at all levels of authority". ${ }^{122}$ With these suitably modest goals came a suitably modest assessment of the then current scene. "[T]here is no basis for claiming that legal education has failed and that practically anything would be better than what we have now. On the contrary it has been generally successful. Everything possible should be done to increase its effectiveness, but great care should be taken to assure that novel expedients supplement existing values and do not destroy them". ${ }^{123}$ Thus, in contrast to McDougal's attempt to get a first year student to make an "evaluation of our system of property on the basis of its attainment of sociological and political values", ${ }^{124}$ Leach wished to "give the student a professional equipment which will enable him to perform the real-estate side of a general law practice". ${ }^{125}$ The layout of the entire course proposed by Leach emphasized the doctrinal considerations to practice, stripped of their systematic attributes such as Beale would have found essential, and as for policy, it was relegated to an appropriately limited role. "If a member of the bar litigates the validity of a covenant or condition restricting the use of land without considering the consequences to the community of this type of restriction, he will be giving his client very

\footnotetext{
${ }^{120}$ Id. 212.

${ }^{121}$ Barton Leach, Property Law in Two Packages, 1 J. LegAL Ed. 28 (1948)

${ }^{122} / d$. 29.

${ }^{123}$ Id., 30.

${ }^{124} / d ., 38$.

${ }^{125}$ Id. , 41.
} 
bad representation. On the other hand, if he draws a will for a Rockefeller ... while reflecting on the inequalities of the distribution of wealth, he is not likely to do the best job of which he is capable". ${ }^{126}$

What Lasswell and McDougal failed to understand was that after the War and its dislocations, the trend was not in the direction of more leftish democracy, but in the direction of privatism, reestablishing nuclear families disrupted by war on new suburban lawns, reestablishing traditional understandings of the lawyer and his work (it was one must remember in the era of Norman Rockwell with his romantic lens soft focused on MidAmerica), and reestablishing traditional ideologies, purged of their foreign elements. It was a replay of the aftermath of World War I, a deeply conservative reaction, and not the continuation of the Second New Deal. Law followed that line as well. The logical edifice was gone, but, where doctrine gave out, only the most ad hoc, lawyerly policy intervened ... security of transactions, protection of the family, antagonism to welschers, compensation for losses ... the status quo writ in traditional lawyers' terms and writ small. Lasswell and McDougal may have better understood what was happening to legal practice than Leach, but Leach knew what would sell. Pound had been victorious, but only after having been stripped of even the mildly critical bite that he had begun with.

The only significant attempt at theoretical understanding of law in these years was that produced by Lon Fuller ${ }^{127}$ and Henry Hart ${ }^{128}$. For both of these men the emphasis was on privateness, on the primacy of the private ordering of private matters and on the thus supplementary role of the State, primarily in aid of those private orderings. On the question of the justification of rules, an explicit, direct justification was never offered. In some ways that fact is curious for no one would claim that the question of democratic values was far from anyone's mind. Indeed, Fuller was obsessed with the question of how to distinguish a "free" from a "totalitarian" legal system. However, the answer given to the basic question of justification paralleled the answers given elsewhere. A decision was justified when made by the body traditionally appropriate to render such a decision using materials traditionally appropriate to the task by means of traditionally appropriate techniques. The high school civics notion of American government - the legislature makes the laws, the judiciary interprets them, and the executive enforces them - had triumphed. Of course, it was dressed up in many ways, most significantly with the notion that each of these institutions had specific, specialized institutional competencies that, if followed, would help assure a proper result. The judiciary, the critical piece in the system, had as its

\footnotetext{
${ }^{126} / d ., 31$.

${ }^{127}$ Here there is no great book. The best entré into the mass of writings are two essays: Kenneth Winston, Introduction, in THE PRINCIPLES OF SOCIAL ORdeR: SeleCted ESSAYS OF LON L. Fuller (Kenneth Winston ed. 1981) and Peter Teachout, The Soul of the Fugue: An Essay on Reading Fuller, 70 MINN. L. REV. 1073 (1986).

${ }^{128}$ Henry Hart \& Albert Sacks, The Legal Process: Basic Problems in the Making and Application of LaW (1958)
} 
special competency the resolution of private disputes centered around "what happened" and made its necessary decisions filling in the interstices between existing norms by, as every student of spoiled cantaloupes knew, ${ }^{129}$ the careful examination of the available legal materials, traditionally conceived, extended in line with their purposes, traditionally understood, by means of the technique of "reasoned (i.e., purposeful) elaboration". Thinking like a lawyer had triumphed again.

This school of thought, accurately dubbed the legal process school, ${ }^{130}$ thus came to assert that democratic values are to be found not in the actual outcomes of decisions, as the Realists had by their critique implicitly claimed and as Laswell and McDougal had directly stated, but in the process of democratic institutions behaving appropriately. All was for the best in this reasonably decent of all possible worlds, if the system was left to behave pretty much as it traditionally had done. And so, the twin problems of authoritative premises and determinate technique had been realigned so that process guaranteed both - working correctly the system provided the premises and was the technique. Process was thus much like legal science had been fifty years before when it provided both the premises and was the technique.

\section{Contemporary Chaos 1965-}

In retrospect the sleight of hand was dazzling. Its purpose, beyond fitting with a dominant conservatism, is less obvious, so I wish to put that question off for a bit. What is obvious is that the trick was discovered quite quickly. Curiously, the important event took place at the height of the dominance of process thinking. The first Sputnik satellite convinced Americans that our educational system was sluggish or worse. In the name of an improvement in science and technology education, accelerated classes, tracking, advanced placement and other educational nostrums were foisted upon the post-war baby-boom generation and their war-time siblings. Debates about what the program did for science and technology remain, but for the law the program generated a great number of students trained to question accustomed understandings of the society in their high school classes and in their college work in the humanities and social sciences. These were the flower children of Woodstock and HAIR. Social policies, brought to the fore in the Kennedy and early Johnson years, especially the civil rights struggles and the war on poverty, added to the questioning that was finally brought to a divisive head in the fight over continuing the Vietnam War. As in the case of each previous war, its termination brought a conservative drawing in that is in evidence yet today.

\footnotetext{
${ }^{129}$ The first problem in the Hart \& Sacks material is "the Case of the Spoiled Cantaloupes".

${ }^{130}$ Bruce Ackerman, Law and the Modern Mind by Jerome Frank, 103 DAEDALUs 119, 123 and see, supra, note 26.
} 
In the law schools much the same pattern could be seen. The arrival of the baby boomers led to the establishment of more new law schools than at any time period since before World War I. ${ }^{131}$ Even with the increase in law schools, however, the demographic pressure firmly turned the now ubiquitous LSAT into the major screening device for entry into the legal profession. Curiously the conjunction of the reinstitution of the draft for law students during the Vietnam War and the rising feminist movement brought large numbers of females into the pool of applicants for the first time; this addition to the pool succeeded in raising demographic pressure beyond what would otherwise have been expected and managed to prolong that pressure, indeed to mask its decline, until quite recently. The decline of the GI Bill as a financing device led to the creation of large pools of subsidized and unsubsidized government assembled funds that were used to finance the education of an increasing percentage of students, creating for the first time an entire class of students who left law school substantially in debt rather than simply penniless. The concomitant increase in the pressure to find well-paying jobs was understandable and luckily, through the early eighties, employment of lawyers was in fact growing as fast or faster than that pressure. Then, the conservative reaction among students set in as jobs became relatively scarce and employers exercised their penchant for wanting their legal education recreated in their employees.

Inside the law schools chaos reigned, not the creative chaos of the so-called student revolution, though briefly, at some places, there was some of that, but intellectual chaos. Required courses decreased in numbers and, in the once sacred first year, in length. In their place electives and seminars of every kind, stripe and color bloomed, not that the students necessarily took them. Students seem, in fact, not to have used their electives to stray much beyond the former required curriculum, a fact that bothered many faculty. ${ }^{132}$ Clinical studies appeared almost everywhere, fueled primarily with Ford Foundation money at the outset and then by student interest, initially in relevant learning, a code word for giving legal assistance to the poor, then later in the understandable hope on the part of those whose were not very good at law school's intellectual games that they might nevertheless be good at practice. No one knew exactly where clinic fit in to a legal education that for years had been clinical only in the most artificial sense. Skills training was proffered as a rationale, but that didn't work well in a world in which litigation, the staple of most clinical programs, was effectively a lost art form; the common alternative rationale - the union of theory and practice - was no better since the practices available in clinics had little to do with any of the law school's more prominent batches of theory or with the office practice most students would enter. Somehow the most plausible justification - a place for bored third year students to hang out - was undercut by the relatively high cost of such education.

\footnotetext{
${ }^{131}$ Again I steal from R. Stevens, supra, note 26, at 232-63.

132 Donald Jackson \& E. Gordon Gee, Bread and Butter: Electives in American Legal Education (1975).
} 
Intellectually chaos reigned too. Legal Process was put to sleep in the sixties and early seventies when it became clear that as a jurisprudence, it could neither explain Brown $v$. Board of Education, the most obviously correct major decision by the Supreme Court of the Twentieth century, nor support the Warren Court's rulings in the areas of criminal procedure and legislative apportionment. Nothing, however, came to replace legal process in the classroom, beyond the soft, warm, but thin blanket that was policy analysis. And even policy analysis came under fire as both left in the form of the Critical Legal Studies movement, and right, in the form of the Law and Economics movement, tried some serious policy analysis from well articulated premises which showed that the standard issue variety was shoddy at best.

At a higher level of intellectual activity, matters may even have been worse. For the first time a significant portion of the intellectual elite among law professors actually possessed more than a nodding acquaintance with a discipline other than law. At one level, the result was the proliferation of a specialized journals like the Journal of Law and Economics and the Law and Society Review. At another level, it meant that the regular law reviews were filled with material that much of the academic profession and most of the practicing profession found increasingly unintelligible. For narrow sub-disciplines - history, sociology and economics come readily to mind - the result was a veritable explosion of literature. But even here there were problems. The economists increasingly produced right and liberal versions of the same material and the historians, liberal and left versions, thus only adding to the cacophony. And, at the level of grand intellectual achievements, many trees were felled to make much paper but just listing the authors (alphabetically to avoid some affront) Ackerman, Dworkin, Ely, Posner, Rawls, Tribe and Unger, makes it clear that there is no dominant school of legal theory in the late twentieth century anymore than there is a dominant idea beyond the chaos elsewhere in the law school.

\section{E. Chaos Explained}

Why is that so? To answer that question, I wish to go back to where I left off a bit ago, to the question as to what exactly was the purpose for the intellectual juggling that was Fuller and Hart.

Politics can explain much about law; after all LAW IS POLITICS as I have said, somewhat aphoristically, before. ${ }^{133}$ The intellectual conservatism of Fuller and Hart mirrored the political conservatism of the late forties and fifties. So too the total political fragmentation of the seventies and eighties is mirrored in the law schools. But politics cannot explain everything. Look at Lasswell and McDougal for example. It is by no means obvious to me

\footnotetext{
133 John Henry Schlegel, Notes Toward an Intimate, Opinionated, and Affectionate History of the Conference on Critical Legal Studies, 36 STAN. L. REV. 391, 411 (1984).
} 
that their scheme of democratic values cannot be turned to quite conservative purposes. Indeed, it is notable that on the one key political issue of the fifties, - McCarthyite anticommunism - the more obviously conservative Harvard types compiled a far better record than their ostensibly more liberal brethren at Yale where individuals deemed to be too left were simply denied tenure. ${ }^{134}$ Yet, Harvard style legal process caught on. To understand why that was so, I think that one has only to look at the two visions of legal education and ask, "Who can teach the stuff?"

Harvard's version could be taught only by lawyers; Yale's was more ambiguous. In fact, it was taught only by lawyers; in theory sociologists might have done as well, economists could have surely helped, as could have social psychologists. That was Realism's problem as well. The facts about law and legal institutions need not have been gathered by lawyers. Indeed, they might well better have been gathered by others. But what then of the law professor; what of his professional identity, his place in the division of labor? Fuller and Hart answered that question quite easily. The law professor was a specialist in understanding legal process, in legal procedure. Just like Langdell's private law curriculum, no one else in the academy knew anything about technical legal procedure nor did they want to learn. The law professor's professional identity, so patiently forged before World War I, was safe, and so the law professors quite easily preferred Leach's road.

Of course, Realism destroyed that identity once before by blasting law out of its doctrinal box. That is why it was so threatening, why Pound reacted so strongly to "some of our younger teachers of law". ${ }^{135}$ Like Wittgenstein's hypothetical parent for whom shooting craps was not playing a game, denying the centrality of the rules was not what sociological jurisprudence was all about; it was simply a new way of justifying the rules. And ultimately, it was Realism that destroyed Legal Process jurisprudence as well. The move, in the now fashionable phrase, was simple to any Realist. Procedures are not neutral; any lawyer knows that. At best, they are tools that are used for substantive ends; at worst they are tools that by their very existence make certain substantive ends more likely, as modern pre-trial practice makes it more likely that wealthy parties will bleed poor parties through the cost of discovery. Process solved nothing. And ultimately it is Realism that can be blamed for the intellectual chaos of today. The cries of the old people about "lost standards" and the danger to a law school of "a professional faculty that has lost interest in most of the work of its alumni", ${ }^{136}$ show quite clearly the lack of any continuing professional identity to the law professor outside of the admittedly trivial one of being able to parse a case.

\footnotetext{
${ }^{134}$ See, Laura Kalman, Legal Realism at Yale (1986).

${ }^{135}$ Nathan Roscoe Pound, The Call for a Realist Jurisprudence, 44 HARV. L. REV. 706 (1931)

${ }^{136}$ Paul Carrington, The Dangers of the Graduate School Model, 36 J. LEGAL ED. 11, 12 (1986)
} 
Now, of course, one can trace the malady back to Ames' action in giving up the teaching of substantive law as the object of law school and substituting therefore "thinking like a lawyer". But in truth the substitution was a phoney one. Law School didn't teach its students to think like lawyers. Lawyers don't think like that. They think in quite concrete, instrumental terms. Law school taught students doctrine pure and simple and incidentally, but only incidentally, how it got manipulated. It taught law from the inside. Realism moved outside the box of doctrine and looked in; at that moment it broke open the academic lawyer's identity.

\section{F. Reflection}

One of the funniest things Bob Gordon ever said was at a New Year's Eve Party on 31 December 1975 when with the stroke of twelve, in mock sadness, he sighed, "Ah, Schlegel Le fin du siècle!" The professional legal academic in the Langdellian mode is approaching one hundred years old. He, now finally he and sometimes she, is a creature of the first fin du siècle. That was a time like the present when political life was hardly secure and orderly. Indeed, there were real socialists in the woods then, real anarchists, real trade unionists. It was order that was being searched for in those days as Robert Wiebe so aptly noticed. ${ }^{137}$ One of those pieces of order that emerged was law and professors. Is similar order likely to emerge again from this in many ways less conflicted political climate or has Realism killed that possibility? In a world where there are semioticians to explain about language and economists to explain about markets, psychologists and sociologists to explain about people and political scientists to explain about government, philosophers to explain about theory and anthropologists to explain about culture, and lawyers, real practicing lawyers, to give real apprenticeship training is there any need for law professors? I do not propose to answer that question but only to note that its answer, which will come in time, will help answer the more basic question, "What was Realism?" Realism, that quintessentially professorial movement, created the problem for its own class, which I have explored in order to help bring you to an understanding of itself. A snake swallowing its tail? Perhaps.

\footnotetext{
${ }^{137}$ Robert WIEBE, THE SEARCH FOR ORDER (1967)
} 